\title{
Thai-Cambodian Conflict: The Failure of ASEAN's Dispute Settlement Mechanisms
}

\author{
Pavin Chachavalpongpun
}

\begin{abstract}
In 2008, the Thai-Cambodian conflict over the Preah Vihear Temple was reignited after the issue became politicized by political groups in Thailand. The opposition accused the Samak Sundaravej government of aspiring to achieve its private interests in exchange for Thailand's support for Cambodia's bid to have the Preah Vihear listed as a UNESCO World Heritage Site. In Thailand, there was a belief that if Cambodia's bid was successful, the country would lose the disputed 4.6-square-kilometer area surrounding the temple. This pushed elements in Thailand to unofficially declare a state of war with Cambodia. This crisis also had a serious impact on ASEAN. Thailand rejected ASEAN's mediating role, thus revealing its distrust in regional dispute settlement mechanisms. For ASEAN, it unveiled its weakness in exercising authority over its members, and its incompetency in the management of regional disputes. This article argues that ASEAN was caught between the need to be a key player in regional politics, especially in tackling territorial disputes in the region, and the need to maintain the region's status quo by appearing subservient to the members' self-interest in protecting their national sovereignty at the expense of progress on regionalization.
\end{abstract}

Keywords Thailand, Cambodia, Preah Vihear Temple, ASEAN, dispute settlement mechanisms, territorial dispute

The conflict between Thailand and Cambodia over the Preah Vihear Temple was reignited in the middle of 2008, when the opponents of Prime Minister Thaksin Shinawatra (2001-2006) politicized the issue in order to undermine the proThaksin regime of Prime Minister Samak Sundaravej (January-September 2008). The military coup of 2006 that overthrew the Thaksin government ultimately failed to eradicate his influence in politics. When the post-coup military regime of Surayud Chulanont (2006-2008) finally returned power to Thai voters, they elected Samak who was honest about his status as Thaksin's political nominee. Upon his assumption of the premiership, one of Samak's first tasks was to endorse the Cambodian bid to have the Preah Vihear listed as a United Nations Educational, Scientific and Cultural Organization (UNESCO) World Heritage

(C) 2013 The Institute for Peace and Unification Studies, Seoul National University

E-ISSN 2288-2707 Print ISSN 2288-2693 
Site.

As part of a move to topple Samak, the royalist People's Alliance for Democracy (PAD), together with the opposition Democrat Party, accused Samak of "selling the nation," or khai chat, in exchange for supposedly personal interests of Thaksin in Cambodia. The accusation was proven to be groundless. Nevertheless, the rhetoric of "selling the nation" remained powerful. There was a belief in Thailand that, in endorsing Cambodia's bid, the country would lose sovereignty over the disputed 4.6-square-kilometer area surrounding Preah Vihear. The fear of losing territory drove a number of Thai nationalist groups to declare war with Cambodia. PAD, the Democrat Party, and elements of the Thai army, played along with the theme lost territories. Finally, armed clashes broke out, and these are considered to be the worst conflicts in the recent history of Thai-Cambodian relations.

It is important to note here that this was not the first crisis in ThaiCambodian relations in modern times. In January 2003, Cambodian patriots burned down the Royal Thai Embassy in Phnom Penh following the allegation made by a Thai actress, Suvanand Kongying, that the famous Angkor Wat belonged to Thailand (Jagan 2003). On the surface, it appeared that fervent nationalist sentiment was responsible for the arson attack against Thai property. In reality, Cambodian nationalism was simply exploited by leaders in Phnom Penh to score political points prior to the elections scheduled for July 2003. Once his domestic political agenda was achieved, Prime Minister Hun Sen of Cambodia quickly normalized his country's relations with Thailand, and his move was reciprocated by his Thai counterpart, Thaksin, who was keen to improve bilateral ties for the sake of his own government's legitimacy. From 2003 to 2008, bilateral relations between the two countries seemed to be normal, as Hun Sen and Thaksin found renewed mutual interest in strengthening their friendship, both at national and personal levels. Although trouble free on the surface, the relationship continued to be influenced largely by the domestic situation in the two countries.

It is fair to say that the 2008 crisis in Thai-Cambodian relations once again was rooted in Thai domestic politics. Also, this time it had great ramifications for bilateral ties, as well as for the reputation of the Association of Southeast Asian Nations (ASEAN), of which both states are members. ASEAN initially expressed concern for the rapid escalation of the conflict which threatened regional peace and security. It pressed to intervene in the conflict, offering to play the role of mediator. However, ASEAN's offer was bluntly rejected by Thailand, particularly when the Democrat Party, led by Prime Minister Abhisit Vejjajiva, was in power (2008-2011). On this basis, Thailand simply bypassed ASEAN's initiative and, more importantly, demonstrated its distrust in regional dispute settlement mechanisms. On the part of ASEAN, the crisis unveiled its vulnerability, particularly in exercising authority over its members, as well as its incompetency 
in managing regional disputes.

This article will attempt to answer three key questions: (1) how did the Thai-Cambodian conflict come about? (2) what were the bilateral and regional approaches in dealing with the problem and, in particular, what was the role of ASEAN? and (3) how can this case be compared with similar cases in Southeast Asia? The article argues that ASEAN confronts a difficult dilemma in the case of the Thai-Cambodian conflict. The need to show the world that it is a serious organization and a key player in regional politics, especially in tackling territorial disputes in the region, conflicts with the need to maintain the region's status quo by appearing supportive of the members' self-interested desire to protect their national sovereignty at the expense of progress on regionalization.

\section{The Haunted Temple}

Due to space and scope constraints, this article does not elaborate on the root cause of the Thai political crisis. However, it is imperative to state at this point that the current problem facing Thailand derives from the competition between those who have aligned themselves with the traditional elite and those who have sided with the masses-with Thaksin identifying closely with the latter group. This intensifying political polarization has compelled the various political factions to find ways to delegitimize their enemies. Also, foreign policy has become one of the political weapons exploited to achieve that purpose.

After assuming the premiership, Samak chose to visit Cambodia in March 2008, as the first country for his introductory tour. Samak's overt enthusiasm about strengthening ties with Cambodia was, however, ill-received by his political opponents. His visit to Phnom Penh was widely publicized by PAD as preparation for possible business deals between Thaksin and Cambodian leaders. On May 14, 2008, a week before Thailand announced its official support for Cambodia's UNESCO bid, Foreign Minister Noppadon Pattama (also Thaksin's personal lawyer) and Deputy Prime Minister Somchai Wongsawat (Thaksin's brotherin-law) were invited to preside, alongside Cambodian Prime Minister Hun Sen, over the opening of the newly renovated 152-kilometer National Highway 48 and a 1,560-meter concrete bridge. The road was built with one billion baht in financial assistance from Thailand that was initially designated to facilitate the transport of goods from Cambodia to Laem Chabang port in Chonburi, Thailand, passing through Trat, a project that would transform Cambodia into a expanded marketplace for Thai products. Noppadon admitted that during this visit he had met with Cambodian Deputy Prime Minister Sok An and discussed the development of a joint management plan for Preah Vihear Temple, which justified the Thai endorsement of Cambodia's UNESCO proposal. ${ }^{1}$

In retrospect, it is clear that the dispute between Thailand and Cambodia 
over the ownership of the Preah Vihear Temple was purposely amplified by antiSamak government agents (Croissant and Chambers 2011). Thailand had lost the ownership case to Cambodia in 1962 after both countries took their overlapping claims to the International Court of Justice (ICJ). The issue had been dormant for over 40 years but was resurrected by PAD in 2008, which took advantage of the dispute to remove Samak from power. (The Samak government had earlier agreed to endorse the Cambodian proposal to UNESCO.) Eventually, Noppadon went on to conclude a Joint Communiqué with Cambodia’s Sok An in Paris, on May 22, 2008, reaffirming full Thai support for the inscription of the Preah Vihear Temple on the World Heritage list. Upon returning home, Noppadon was greeted at Suvarnabhumi International Airport by furious PAD nationalists who called him a traitor. PAD claimed that the government had ceded 4.6 square kilometers of disputed land near the temple to Cambodia in exchange for business concessions for Thaksin (Reuters 2008). The discourse on lost territories, first used during the colonial period when Siam supposedly lost some territories to European powers, was revived to serve a variety of interests of the traditional elite and of the military (Thongchai 2008). PAD nationalistic rhetoric, employed to taint the image of the Samak government, also severely impaired diplomatic ties between Thailand and Cambodia and opened old wounds of mutual antagonism between the people of the two countries.

As PAD continued to fan the flames of nationalism, the Administration Court stepped in and ruled that Noppadon's Joint Communique with Cambodia was unconstitutional (Thiradej and Ram 2008, 62-3). Meanwhile, Sondhi Limthongkul, one of the core leaders of $\mathrm{PAD}$, proposed a radical solution to the conflict.

A commission must be set up to invite Cambodia to bilateral negotiations. If the dispute could not be settled, Thailand would, temporarily adhere to the ICJ's ruling, mobilise Thai troops, push Cambodians back from Thai territory, and formally inform Cambodia that, apart from Preah Vihear Temple, the surrounding land belongs to Thailand, and Thailand would pay any price to protect its sovereignty, even at the cost of war. (Prachatai 2008)

Under tremendous pressure, Noppadon resigned as Foreign Minister on July 10, 2008. Nevertheless, his resignation did not terminate the Thai-Cambodian conflict. Rather, it marked the beginning of a new surge in mutual antagonism between the two countries as the bilateral dispute became more violent. On August 3, 2008, the first armed clashes broke out near the Preah Vihear Temple, primarily due to PAD's provocation, resulting in the death of one Cambodian soldier.

Samak was forced to step down as prime minister in September the same year following a bizarre charge of his appearing in a televized cooking show. 
Thaksin's brother-in-law, Somchai, then took over the premiership. PAD and the military elite continued to utilise the Preah Vihear issue to eliminate Somchai. PAD managed to mobilize thousands on the streets of Bangkok to protest against the new prime minister for working on behalf of Thaksin in selling out the motherland to the "Khmer enemy." Riding on the wave of anger among the PAD nationalists, the Thai military, which also perceived Thaksin and his cronies as its enemies, began to launch its first attacks against Cambodia, with the aim of further weakening public confidence in Somchai. On October 3, 2008, the second armed clash took place at Phu Ma Khua, 2.5 kilometers west of the Preah Vihear Temple. It was reported that two Thai rangers were injured in the exchange of gunfire. On October 15, 2008, one Thai and three Cambodian soldiers died in an exchange of rifle and rocket fire when their troops clashed at the border. Hun Sen responded with heated rhetoric: "Thai troops must stop trespassing on Cambodian land; the contested territory is now a life-and-death battle zone" (Perry 2008).

In order to further exacerbate the situation, Kasit Piromya, member of the opposition Democrat Party and a self-proclaimed pro-PAD, anti-Thaksin personality, actively supported PAD and the army. On October 14, 2008, Kasit, in a television interview, attacked Hun Sen using extremely vulgar language. He branded Hun Sen a "lunatic leader," a "slave" of Thaksin and a "gangster" of Southeast Asia. ${ }^{2}$ A day later, another clash erupted along the common border resulting in the deaths of one Cambodian and three Thai soldiers. Cambodia felt that it had become a victim of the Thai domestic political struggle between Thaksin and the traditional elite. Since he maintained close personal relations with Thaksin, Hun Sen retaliated against the Thai elite by publicly lending his support to the Somchai government and the red-shirt movement. This indicated an immense mutual hatred between Hun Sen and the Thai traditional elite and explained why Hun Sen adopted a hostile policy toward the anti-Thaksin Democrat Party when Abhisit finally became prime minister.

\section{Inviolable National Security}

It was not the dispute over Preah Vihear Temple that brought down the Somchai government. Exercising its ultimate measure, PAD seized Suvarnabhumi International Airport and Don Muang Airport in late November 2008, creating a state of ungovernability so severe that the military threatened to stage another coup to end the turmoil. However, before this could take place, the Constitutional Court intervened in the crisis, launching an alternative "judicial coup" that resulted in the collapse of the Somchai government. The Court ruled that his People's Power Party (PPP) had committed electoral fraud in the December 2007 elections. The Court's president, Chat Chonlavorn, said that he was dissolving the parties "to set a political standard and an example." "Dishonest political parties undermine Thailand's democratic system," Chat said in the court's ruling (Weaver 
2008). The sudden downfall of the Somchai regime led to a new twist in Thai politics as it allowed the Democrat Party, a minority in the parliament, to form a coalition government through a backroom deal brokered by the military (Roberts 2008). The assumption of power by the Democrat Party, with Abhisit, an Oxfordeducated politician with an elitist background, as prime minister, caused a further deterioration in Thai-Cambodian relations.

During this transition from Somchai to Abhisit, from late 2008 to early 2009, relations between Thailand and Cambodia went from bad to worse. This was simply because the Abhisit government intentionally handpicked Kasit, an anti-Hun Sen figure, to serve as foreign minister. Kasit was on a mission to purge Thaksin loyalists and the latter's diplomatic style, including his businessoriented foreign policy, in order to justify his government's anti-Thaksin stance, and even the 2006 coup. The Democrat Party, once it joined forces with PAD in politicizing the Preah Vihear issue, now found itself locked in its earlier hostile attitude towards Cambodia, and was therefore compelled to stick with its antiCambodia campaign even when it had an opportunity to mend the broken ties. It is also noteworthy that due to the fact that the Democrat Party had arrived in power with the help of the military, the government owed much to the army elite. With the Abhisit government remaining in the long shadow of the military, the latter immediately prioritized the border conflict with Cambodia, rationalizing its stance in terms of a challenge to national security. Also with Kasit, Thailand's foreign minister, continuing to upset the Cambodian leadership with his offensive language and antagonistic posture, the border zone became a battlefield. The Democrat-led government went along with the military in reshaping Thailand's foreign policy towards Cambodia to become, once again, security-centric. ${ }^{3}$

\section{Deterioration of Relations}

Thus, the beginning of the Abhisit government was colored by heightened antagonism between Thailand and Cambodia. For most of the government's life, bilateral relations could be described as disturbingly erratic or even bloodily confrontational. Thai-Cambodian relations were simply a casualty of Thailand's domestic politics which reflected the military's domination of internal and external policies.

Three months after the military helped stage-manage the Abhisit regime, armed clashes between the two countries resumed. In late March 2009, about 100 Thai troops briefly entered contested territory near the Preah Vihear Temple. Hun Sen immediately warned Thailand of Cambodia's possible forceful counterattack. Eventually the two countries' armies clashed on April 3, 2009, leaving two Thai and two Cambodian soldiers dead and several injured. Thailand closed access to Pha Mo E-Daeng cliff and the Khao Phra Wihan National Park, gateway to Preah Vihear Temple in Si Sa Ket Province. Prior to the fatal shootings, Cambodia had deployed more than 3,000 soldiers at the ancient 
temple ruins and Thailand had slightly over 2,000 troops on Pha Mor E-Daeng cliff (Wassana, Thanida, and Prasit 2009). The armed clashes were encouraged by a new nationalist boast by Hun Sen's rabble-rousing and by Kasit's never-ending insults against the Cambodian leadership. One month after the fatal shooting incident, Cambodia demanded Thailand to pay compensation for damage resulting from the confrontation on the border. In its diplomatic note, Cambodia stated: "The attack with heavy weapons by Thai troops on Cambodian territory caused much damage and set a Cambodian market ablaze. The material losses to 319 families, who had lost their livelihoods when the fire destroyed their market stalls, amounted to more than 2.1 million US dollars" (Bangkok Post 2009). Not only did the Thai side refuse to provide compensation, Prime Minister Abhisit rekindled the nationalistic impulse by requesting that UNESCO review the World Heritage status of the contentious temple when the UNESCO committee met in Spain in late June 2009. Cambodian Foreign Minister Hor Namhong angrily challenged the Thai objection: "Cambodia welcomes Thailand militarily, diplomatically, internationally, or through peaceful negotiations. I heard that the second Thai commander on the border put his troops on alert and I would like to tell them that Cambodian soldiers are also on alert" (The Nation 2009).

During the ASEAN Summit in Hua Hin in October 2009, Hun Sen further infuriated Thai patriots by announcing that he would appoint Thaksin as his government's economic advisor. The appointment was made official by virtue of a Royal Decree in the Cambodian capital on November 4, 2009. The fact that Cambodia's cabinet as well as Cambodia's King Sihamoni endorsed the appointment of Thaksin affirmed Hun Sen's plan to collaborate with Thaksin in destabilizing the Abhisit government. Meanwhile, the Thai government adopted harsher diplomatic measures against Cambodia. On November 6, Kasit recalled the Thai ambassador to Phnom Penh to protest against Cambodia's official appointment of Thaksin. He also decided to review all bilateral agreements with Cambodia and withdraw from maritime talks focused on potential rich supplies of oil and gas in a disputed area of the eastern Gulf of Thailand. Cambodia retaliated by recalling its ambassador to Bangkok and accused Bangkok of overreacting (Supalak 2009a). The Thai military, riding on the notion of national security and the discourse on nationalism, painted a deadly scenario of a possible new round of armed clashes. It built 340 bunkers in villages in Si Sa Ket Province near the site of the Preah Vihear Temple as a sign of this unease (Marwaan 2009). While the Abhisit government in Bangkok created a stage for the protracted conflict with Cambodia, and PAD continued to arouse nationalist sentiment among Thais, the military transformed this intense atmosphere into tangible armed clashes along the Thai-Cambodian border.

During the Abhisit administration, there were altogether six armed clashes between Thailand and Cambodia: one in 2009, three in 2010, and two in 2011 (see Table 1). 
Table 1. Armed Clashes between Thailand and Cambodia (2008-2011)

\begin{tabular}{ll}
\hline \hline \multicolumn{1}{c}{ Date } & \multicolumn{1}{c}{ Incidents/Consequences } \\
\hline August 3, 2008 & An exchange of fire near Preah Vihear injured one Cambodian \\
\hline October 3, 2008 & $\begin{array}{l}\text { Clashes at Phu Ma Kua (2.5 km west of Preah Vihear), no casualties } \\
\text { reported }\end{array}$ \\
\hline October 15, 2008 & $\begin{array}{l}\text { An exchange of gunfire left three Cambodian soldiers and one Thai } \\
\text { soldier dead }\end{array}$ \\
\hline April 8, 2009 & Heavy gunfire erupted and killed two Cambodian and two Thai soldiers \\
\hline January 24, 2010 & Exchange of gunfire, no casualties reported \\
\hline January 29, 2010 & A brief shootout, no injuries reported \\
\hline June 8, 2010 & Exchange of gunfire, no casualties reported \\
\hline February 4-7, 2011 & $\begin{array}{l}\text { Heavy fire exchanged at Phu Ma Kua, killing two Thai soldiers and one } \\
\text { civilian, and at least three Cambodian soldiers }\end{array}$ \\
\hline April 22, 2011 & $\begin{array}{l}\text { Cambodian troops opened fire on Thai troops near Ta Kwai and Ta } \\
\text { Muen Temples; four Thai soldiers and three Cambodian soldiers killed }\end{array}$ \\
\hline
\end{tabular}

Source: Bangkok Post 2011.

The Abhisit era witnessed the most frequent and deadly armed clashes between Thailand and Cambodia since the end of the Cold War, and indeed since the 2006 coup. These were manufactured to serve a variety of political purposes, primarily those of the Thai defence establishment. True, the tension with Cambodia was first stirred up as a ploy to overthrow the two pro-Thaksin regimes in 2008. However, it was a mistake to assume that the Thai-Cambodian situation would improve under the leadership of Abhisit after the Thaksin cronies were driven out of power. The continuity of fatal confrontations between the two countries unveiled the reality whereby the military still gained ample benefits from maintaining a war footing with Cambodia. This time the purpose, however, was not to unleash external war to undermine internal enemies but more to perpetuate the army's power position in politics.

There is evidence to demonstrate the military's attempt to intensify, directly or otherwise, the conflict with Cambodia. In late December 2010, PAD felt that its movement was fast losing its place in the political limelight, and therefore it sought to stir up yet another round of disputes with Cambodia to regain its political leverage. PAD sent its members, some from the Thai Patriots Network, together with Panich Vikitsreth, a member of parliament from the ruling Democrat government, to cross into Cambodia illegally. Consequently, they were all arrested for encroaching on Cambodia's territory-an incident that successfully outraged the anti-Cambodia movement in Thailand (Bangkok Post 2011a). With this incident, PAD pressed Abhisit to take a tougher line towards 
Cambodia, including the military option, unless all of those arrested were released. Finally, a Cambodian court did free five of them, including Panich while the other two, Veera Somkwamkit and Ratree Pipattanapaiboon, remained in a Phnom Penh prison charged with illegal entry and espionage. After serving over two years of their sentences, Ratree was granted a royal pardon (Bangkok Post 2013). However, Veera is still detained in Cambodia.

PAD deliberately urged the Thai military to intervene in the conflict with Cambodia. More fundamentally, it enabled the military to resurrect the old political culture in which the army had maintained powerful control over civilian rule, particularly in foreign affairs. The crisis in the border area that resulted in Thai nationals being arrested on supposed Thai territory, breathed new life into the old discourse on lost territories among the Bangkok elite and the defence establishment. Foreign Minister Kasit claimed that these Thais were captured in Thai territory, which appeared to contradict what Veera, one of the captives, had said in a video clip recorded during the crossing into Cambodia. Veera said with laughter: "We are now in Cambodian territory. Wait, soon the Cambodians will come and arrest us. And we will be rescued by Thai soldiers."4 The Cambodian authorities, however, did not find their illegal entry amusing. The arrest sparked a series of armed clashes between the two sides, lasting from January to April 2011. The imprisonment of the PAD members also helped prolong the bilateral conflict, and thus extended the Thai military's influence on politics (Waddhana 2011).

PAD's agitation proved highly effective. It was followed by fresh armed clashes which lasted for four days, from February 4 to 7, 2011. The Thai army was accused of using cluster bombs to attack Cambodia, an allegation made by the Cluster Munition Coalition (CMC). The CMC claimed the Thai army killed two Cambodian soldiers with 155-millimeter Dual Purpose Improved Conventional Munition (DPICM) cluster bombs during the border fighting. Thailand is not among the 107 countries that have signed the Convention on Cluster Munitions, banning their use. Defence Minister General Prawit Wongsuwan later rejected the CMC allegation: "No cluster bombs here. We have strictly complied with international laws banning their use" (Bangkok Post 2011c). It was also reported that the Thai military deliberately bombarded the Preah Vihear Temple complex, causing serious damage (BBC News 2011).

In April 2011, fighting again erupted. This time, the two countries fought to gain control over two relatively unknown temples hidden deep in the jungle off the main tourist trail-Ta Kwai and Ta Muen Tom in Thai, or Ta Brabei and Ta Moan in Khmer. The two temple ruins were purposely dragged into the persistent border conflict. Estimated to be at least 800 years old, the temples are located 15 kilometers apart and around 150 kilometers west of Preah Vihear Temple, which has traditionally been at the center of bilateral unrest. Thailand and Cambodia have both laid claim to the ruins. The two ancient temples are among several elegant Khmer architectural structures built to honor Hindu deities. Historians 
believe that both may have been constructed around the same time as Preah Vihear (Strait Times 2011). The Thai military took advantage of the nationalistic emotions that run deep in Thailand. Its aggression vis-à-vis Cambodia was legitimized by the prevailing discourse on lost territories that gave birth to nationalist forces, driving the country into deadly conflict with Cambodia.

\section{Bilateral Negotiations versus ASEAN's Multilateral Approach}

At the height of the crisis, with the Abhisit government reluctant to defuse the conflict with Cambodia, it was not only Thailand that suffered damage to its image on the international stage, but ASEAN was also negatively affected. The test of Thai leadership in the Preah Vihear conflict was just as much a test of the credibility of ASEAN.

\section{Conflicting Approaches}

Indonesia, the world's most populous Muslim country, which is naturally the leader of ASEAN, was the ASEAN chair in 2011. Furthermore, its recent emergence as an up-and-coming democratic country, now the third largest democracy in the world, positions it to play a principal role in ASEAN. ASEAN has recently undergone its own reinvention, with the launch of the ASEAN Charter in 2008 and the rescheduling of its community building initiative, now to be accomplished by the end of 2015 (Severino 2006). Such new developments added immense pressure on both ASEAN and Indonesia to intervene in the ThaiCambodian conflict, using the existing dispute settlement instruments, to prevent the two countries from going to war. However, ASEAN's offer to play a mediating role was only half-heartedly accepted by the Abhisit government. Compelled to cooperate with ASEAN for the sake of the organization's credibility, the Abhisit government reluctantly consented to Indonesian observers being stationed in the disputed area-a decision fully agreed upon by Cambodia.

ASEAN Foreign Ministers finally gathered in Jakarta for an urgent meeting facilitated by Indonesia on February 22, 2011 to discuss possible solutions to the border conflict. ASEAN Secretary-General Surin Pitsuwan was quick to celebrate ASEAN's success: "ASEAN is certainly rising to the occasion." In reality, Thailand continued its foot-dragging approach and did little to facilitate insertion of the ASEAN monitoring team led by Indonesia. While the Abhisit government pledged to work with ASEAN to alleviate the border tension, the Thai military insisted on managing the problem strictly on a bilateral basis, relying on the Memorandum of Understanding (MOU) on border issues signed by Thailand and Cambodia in 2000, and two organizational frameworks-the General Border Committee (GBC) and the Joint Border Committee (JBC). ${ }^{6}$ Thailand's policy inconsistency reflected the complex pattern of Thai foreign policy decision- 
making. The fact that Thailand failed to properly involve ASEAN, despite its pledge to the organization, demonstrated that the military, not the Foreign Ministry, was the key actor in making foreign policy decisions regarding the country's relations with Cambodia.

Evidence of the military influencing Thai foreign policy towards Cambodia is copious. Both Defence Minister Prawit Wongsuwon and Army Chief Prayuth Chan-ocha declared that they would not attend the 8th GBC meeting with Cambodia in Bogor in April 2011, organized by Indonesian Foreign Minister Marty Natalegawa on behalf of ASEAN. Prawit stressed: "No, I am not going. Why should I go for the meeting in a third-party country? Thailand and Cambodia know each other well enough and do not want any other party to get involved." Prayuth added: "Cambodia's proposal to set up 15 joint border checkpoints in the disputed 4.6-square-kilometer area near Preah Vihear Temple was unnecessary. The dispute could be solved through military talks" (Wassana and Pradit 2011). As a reporter elaborated:

Defence Minister Prawit Wongsuwon and commanders of all armed forces have resolved not to allow Indonesian observers to enter the 4.6 square kilometre dispute area on the Thai-Cambodian border, Army Chief Prayuth Chan-ocha said on Wednesday. General Prayuth insisted the top brass wanted the Thai-Cambodian conflict to be solved by the two countries only. He said the army had made a proposal to Cambodia through the Foreign Ministry that if there are to be joint checkpoints in the disputed area a centre should be set up to coordinate their operations. The coordination centre must be manned by Thai and Cambodian soldiers only. It is not necessary to have Indonesian observers (Wassana 2011).

Thailand's two conflicting approaches, one endorsed by Prime Minister Abhisit in agreement with ASEAN's mediation, and the other adopted by the Thai military which concentrated on a bilateral framework, clearly revealed that the country was not genuinely committed to solving the conflict with Cambodia. The nature of Thai politics in the post-coup period pointed to the fact that the civilian regime of Abhisit remained weak and subservient to the military. Abhisit's political ascendance, with the support of the military, could not hide the reality that the defence establishment was the real power behind the conduct of Thai foreign policy with Cambodia.

Having lost trust in bilateral mechanisms, Cambodia decided to turn to the United Nations (UN) requesting it to intervene in the escalating violent clashes with Thailand. But in the end, the UN sent a signal to Phnom Penh that since both Cambodia and Thailand are members of ASEAN, which has its own dispute settlement mechanisms, they should first consult with ASEAN and try to find a solution through existing regional frameworks. This would prevent the conflict from becoming internationalized.

Cambodia's frustration with Thailand also stemmed from the fact that 
Bangkok, under the Abhisit regime, wanted to withdraw its earlier support to have the Temple listed as a World Heritage Site. Thailand's withdrawal of its support directly affected Cambodia's management plan around the Temple. Thailand claimed Cambodia's development plan for the disputed 4.6-squarekilometer area was a breach of Thai sovereignty. More importantly, Cambodia felt it urgent for the conflict to be resolved quickly since it had caused considerable casualties on both sides. Accordingly, the Cambodian Foreign Minister, Hor Namhong, speaking at an ASEAN meeting in Singapore in 2008, pleaded with ASEAN to help find a breakthrough in the confrontation. (In 2008 Singapore was ASEAN's chair.) In his letter to the Singaporean Foreign Minister, who led the 15th ASEAN Regional Forum in July 2008, Foreign Minister Hor wrote: “Thai troops with artillery and tanks are building up along the border, constituting a very serious threat not only to the sovereignty and territorial integrity of Cambodia, but also to peace and stability in the region" (Cheang 2008).

The request was sent in 2008, but it was not until the beginning of 2011, at the peak of another deadly confrontation between Thailand and Cambodia, that ASEAN began to make a concrete move. To alleviate the tension, ASEAN convened a Foreign Ministers Informal Meeting on February 22, 2011. Indonesia, as ASEAN's chair, released a statement that reminded the Cambodian and Thai leaders of their commitment to the principles contained in ASEAN's Treaty of Amity and Cooperation (TAC) and its charter, including "settlement of differences and disputes by peaceful means" and "renunciation of the threat or the use of force." It urged both sides to resume bilateral negotiations as soon as possible, with the appropriate engagement of Indonesia. ${ }^{7}$ While Cambodia swiftly accepted the terms of reference for unarmed Indonesian military observers to monitor a ceasefire along the border near the Preah Vihear Temple, Thailand was unwilling to have a third party involved in the conflict. The Abhisit government was under immense pressure from the nationalist PAD group, which submitted a letter on March 10, 2011, to the Indonesian Ambassador in Bangkok, protesting against the planned Indonesian observer mission to the Thai-Cambodian border. The letter stated that Indonesia's terms of reference would mean "a foreign military operation to control a Thai military operation defending Thai sovereignty, which has been deliberately violated by Cambodia," and that the proposed Indonesian observers would not comply with the bilateral arrangement between Thailand and Cambodia aimed at solving the border dispute (Charnvit, Sothirak, and Pavin forthcoming). PAD further urged the Thai government to push Cambodian troops out of the disputed area and to walk away from the World Heritage Convention (Xinhua News 2011).

Despite the willingness of ASEAN to mediate the conflict, military troops were still entrenched along the frontier. Another round of clashes occurred toward the end of April 2011, expanding from the disputed area near the Preah Vihear Temple to a wider area along the border between the two countries. 
Cambodia once again sent a protest letter to Indonesia and asked ASEAN to inform the UN Security Council (UNSC) of what Cambodia called "Thai armed forces' military aggression against Cambodia." Seeing that the border tension was dragging on far too long, exacerbated by pressure from Thai nationalist groups and the military, Cambodia finally decided to ask the ICJ for a new interpretation of its earlier judgement that gave Cambodia ownership of the Preah Vihear Temple. On April 28, 2011, Cambodia filed an application requesting reinterpretation of the judgment rendered on June 15, 1962 by the ICJ in the case concerning the Temple, together with an urgent request for implementation of provisional measures. As of this writing the ICJ has yet to issue a ruling on the Cambodian request. However, it has called for both sides to withdraw their troops, forming a temporary demilitarized zone, and to allow Indonesian observers to have access to the area (Charnvit, Sothirak, and Pavin forthcoming).

\section{The Failure of ASEAN}

The armed clashes between Thailand and Cambodia have seriously undermined ASEAN, particularly during a time when it has aspired to build its own political and security community. On February 5, 2011, ASEAN Secretary-General Surin gave an interview emphasising that the ongoing dispute had undermined ASEAN's credibility and affected members' economic recovery. Surin pleaded with both sides to allow ASEAN to help them negotiate a temporary truce and reduce tensions, so that the interests of both parties and that of ASEAN could be protected and enhanced. A few days later Indonesia sent its Foreign Minister, Marty Natalegawa, to Phnom Penh and Bangkok, to search for an urgent truce between the two countries' armies. After Marty's return to Jakarta, Indonesia hosted an ASEAN Informal Meeting, on February 22, and invited Thailand and Cambodia to brief the members on the situation and to elaborate their own positions vis-à-vis the ideal solution to the dispute. Finally, ASEAN members agreed that bilateral negotiations must be resumed with appropriate engagement by Indonesia and ASEAN's chair. But as much as Surin and Marty wished for a greater and more forceful role for ASEAN in solving the crisis, ASEAN had its own limitations-its organizational weaknesses which have continued to damage its credibility. On top of this, it was known in Phnom Penh that the Cambodian leadership did not really trust Surin, who is a Thai citizen and, more importantly, a member of the Democrat Party. ${ }^{8}$ This partly explained the difficulty encountered by the Secretary-General in his attempts to tackle the crisis.

ASEAN had exercised its leadership in dispute settlement in the past but had met with little success. Simply put, this is because ASEAN's dispute settlement mechanisms lack enforcement and compliance authority over its members. ASEAN has produced key documents over the years which all members have successfully ratified, but it is still managing the organization based on informality and personal friendship among national leaders (Rasak 2009, 20). So when they 
encounter sensitive issues, such as sovereignty-related conflicts, human rights violations or state crimes, the members tend to call for upholding of the noninterference rule which has been the cornerstone of ASEAN from the beginning (Ramcharan 2000, 60). Some members are themselves vulnerable to accusations of failing to protect the human rights of their own people, and so are reluctant to preach to other members. There are at least four documents that spell out the need to manage conflicts among members in a peaceful manner that all members are bound to abide by. First, the Bangkok Declaration of 1967, the document that established ASEAN in that same year, stipulates that "settlement of differences or disputes by peaceful manner" is one of the fundamental principles of ASEAN. Second, the Treaty of Amity and Cooperation (TAC) of 1976 similarly states the importance of "settlement of differences or disputes by peaceful means." Third, Article 23 of the ASEAN Charter, launched in 2008, encourages parties to a dispute to "request the Chairman of ASEAN or the Secretary-General of ASEAN to provide good offices, conciliation or mediation." And fourth, in invoking the TAC provision, the ASEAN Political-Security Community (APSC) Blueprint, which sets guidelines for the realization of the ASEAN Political-Security Community by the year 2015, also calls for prevention of disputes and conflicts from arising between member states. But as mentioned above, despite the numerous documents adopted by ASEAN members, none of the documents has a provision that compels parties to a dispute to seek ASEAN's involvement. This only underscores that bypassing ASEAN or rejecting ASEAN's role in mediation further diminishes the organization's value and its credibility.

There are many examples of the lack of authority on the part of ASEAN in dispute settlement. In 1977, when Philippine President Ferdinand Marcos decided to withdraw his country's claim of sovereignty over North Borneo, he reportedly declared: "As a contribution to the future of ASEAN, I wish to announce that the Philippines is taking definite steps to eliminate one of the burdens of ASEANthe (Philippine) claim to Sabah" (Nugroho 1994, 6). Of course, it became clear that neither he nor his successors would ever take those definite steps. Marcos only cited ASEAN's value in weighing disputes among member states that also claimed sovereignty over Sabah. In other words, by citing ASEAN, it gave him added legitimacy in his position vis-à-vis his country's claim over Sabah. ASEAN's involvement in other regional disputes include its opposition to Vietnam's incursion into Cambodia in December 1978 and the occupation of that country for most of the 1980s. At that time, however, neither Vietnam nor Cambodia were members of ASEAN. The reason behind ASEAN's involvement was that Thailand, as a frontline state facing the threat of communism, was successful in "Aseanizing" policy toward the Vietnamese threat. Thus, it was more about protecting Thailand's national security, using the name of ASEAN, than about preventing the conflict from affecting Southeast Asia as a whole.

It is true that, following Vietnam's withdrawal of its troops from Cambodia, 
ASEAN was quick to nominate itself as peacemaker in the political settlement of the Cambodian conflict. Some argued that ASEAN's mediation enabled the role of the UN in pushing for a breakthrough in finding a lasting solution to the crisis. Others, however, argued that regional circumstances, with the end of the Cold War, indeed compelled ASEAN to intervene in the Cambodian conflict (Bercovitch 2008, 33). ASEAN had had no prior experience in dispute settlement and was relatively new to emerging concepts such as political rehabilitation and internal reconciliation processes. These concepts deal directly with domestic politics, an area in which ASEAN has tended to avoid involvement. ASEAN has been more effective in settling disputes related to the ASEAN Free Trade Area (AFTA), such as those between Malaysia and Thailand and between the Philippines and Singapore. These trade disputes have been considered somewhat less sensitive in an organization that is predominantly security-centric.

ASEAN leaders fully understand that existing dispute settlement mechanisms may not be working in all cases. Nevertheless, they appear to be satisfied with handling disputes between members by referring to the golden rule of "quiet diplomacy" (Haacke 2003). ASEAN has also claimed that, since its establishment in 1967, it has been successful in preventing armed conflict between members by means of consultation, persuasion and negotiation (Kurus 1993, 819). This claim could be considered fairly accurate, until the Thai-Cambodian mini-war broke out in 2008. Until then ASEAN leaders were proud of being able to mitigate regional tensions without having to rely on dispute settlement mechanisms. Peer pressure and the emphasis on face-saving seemed to be rather effective as they could be used to influence behavior among ASEAN members. But the international environment has changed, and so have the regional dynamics. The end of the Cold War has dangerously exposed old historical wounds that have rekindled antagonism between some members of ASEAN. The case of the ThaiCambodian conflict has demonstrated that not only has ASEAN's interpretation of history become irrelevant, but also the weak mechanisms and symbolic peer pressure used by ASEAN have failed to prevent crises from further escalation. To make matters worse, ASEAN has suffered from two factors that contribute to its incompetency in dealing with bilateral conflicts: the crisis of the "ASEAN way" and the lack of a coherent position vis-à-vis a given conflict.

In the wake of the unrelenting conflict between Thailand and Cambodia, there was no doubt that Indonesia was enthusiastic to play a leading role in finding a solution, purportedly to save ASEAN's face. Indonesia was the right choice in spearheading this campaign to end the dispute. First, Indonesia was the chair of ASEAN that year (2011). Also, it was one of the founding members of ASEAN, and Indonesia has been recently identified as "an emerging democratic state in Southeast Asia." Furthermore, Indonesia was the site where two Bali Concords, the TAC and the APSC Blueprint, were signed. In fact, Indonesia has become a leading proponent of the APSC. Indonesia's ambitious leadership has 
not only served to benefit ASEAN, but has also enhanced its own diplomatic standing. Before the launch of the ASEAN Charter in 2007, some Indonesian academics, feeling let down by the progress of ASEAN, called for their country to leave ASEAN behind and even to develop a post-ASEAN foreign policy (Sukma 2009). Thus, a renewed eagerness in ASEAN affairs on the part of Indonesia could be viewed as another attempt to revive the organization as much as to expand Indonesia's own diplomatic activism. Foreign Minister Marty, in particular, came across as an ambitious diplomat. His success in brokering a peace deal between Thailand and Cambodia would have positioned him at the forefront of international affairs. Unfortunately, Marty worked under extremely difficult circumstances, lacking the full-fledged support of other ASEAN members, and more importantly, constrained by the old modus operandi of the organization based on the rule of non-interference. Thailand, a party to the conflict, was among those who made Marty's effort a "mission impossible." This demonstrated the crisis of the traditional ASEAN approach.

The Thai-Cambodian crisis also exposed another problem besetting the organization-the lack of a coherent position. While some members, such as Indonesia and Singapore, were keen to help solve the crisis, others preferred to take a low-key position. Neither comment nor suggestion was heard from Myanmar, Laos, or Brunei. These countries were not negatively affected as they were not parties to the conflict, and thus they saw no reason to take a decisive stance in support of Indonesia's initiative. They chose to "sit on the fence." On the one hand, sitting on the fence would serve one key purpose-not upsetting either Thailand or Cambodia. Taking no position would mean making no enemy. On the other hand, condemning Thailand or Cambodia and agreeing with the Indonesia's intervention in the conflict could set a "standard" that might not benefit them in the future. ASEAN's intervention in disputes has been perceived as a danger to the majority of regimes in Southeast Asia. The absence of a common position among members has resulted in the failure of ASEAN's dispute settlement efforts.

\section{Current Status}

Thailand's election of July 2011 significantly changed the country's political landscape. The new premier, Yingluck Shinawatra, the first female leader in the country's history, who is the youngest sister of Thaksin, formed a Pheu Thailed coalition government occupying 300 parliamentary seats out of the total 500. The triumph of Thaksin's faction represented a threat to the Bangkok elite. Immediately, the Yingluck premiership was celebrated in Phnom Penh. Cambodia happened to be the chair of ASEAN in 2011, and Prime Minister Hun Sen sent a congratulatory note to Yingluck, vowing to work with her to alleviate tensions. Hun Sen wrote: "I am optimistic that with a joint commitment, Your Excellency and I will obviously be able to restore our traditional friendship, 
good neighbours, and fruitful cooperation between our two countries' peoples. I am ready to work closely with Your Excellency to serve the interests of our two countries and peoples, and to solve all issues peacefully in order to bring good harmonisation to our nations and to contribute to peace, stability and prosperity in the region" (Cambodia Daily News 2011).

Yingluck's much-publicized visit to Phnom Penh, on September 15, 2011, symbolized a thaw in Thai-Cambodian relations. Thaksin followed up with his own visit to Cambodia (September 16-24, 2011) which helped pave the way for a better relationship. In addition, a football match was organized on the day Thaksin arrived in the Cambodian capital between a red-shirt team and that of Cambodia, highlighting the fact that Cambodia has all along played a Thai domestic political game. The détente between Thailand and Cambodia may, for the time being, bury bitter memories between the two countries-but for how long? Here, it must be understood that even if relations between the two countries have become normal under the Yingluck government, it does not necessarily mean that the military is willing to surrender its role in foreign affairs. The popular support which Yingluck has earned following her electoral triumph may have allowed her to intervene in the Thai-Cambodian crisis, but the military has continued to create an environment of volatility along the border to justify its role in foreign policy.

In the middle of 2012, Hun Sen and Yingluck decided to implement Indonesia's peacemaking initiative and agreed to withdraw their country's troops from the disputed area. Obviously, the ceasefire was achieved, at least for now, because of the change in Thailand's domestic politics, rather than any compelling instrumentality of ASEAN. Meanwhile, Yingluck is trying to negotiate with the Thai army for reopening the dialogue between Thailand and Cambodia. It seems to suggest that, in exchange for the army's cooperation on the Preah Vihear issue, the government has agreed not to interfere in the military's internal affairs, including the annual leadership reshuffle and the military's budget. The bilateral consensus to de-escalate the situation along the Thai-Cambodian border has also benefited the interests of ASEAN and the Indonesian negotiators, but this must not be confused as ASEAN's own accomplishment in peacemaking. The onus of avoiding armed conflict continues to rest primarily on Cambodia and Thailand. For the time being, it appears that the leadership groups in the two countries have been able to tamp down nationalistic emotions, instead of actively fanning them as was seen during 2008-2011 period. It will be interesting to see whether the reinterpretation of the 1962 verdict of the ICJ, expected to be announced in October 2013, will shift the positions of the two countries again (Rodas 2012). If the ICJ rules in favour of Cambodia as it did in 1962, this could resurrect nationalistic fervor in Thailand and might reignite armed clashes. The Thai military could benefit from such an outcome, but ASEAN will certainly be put to the test. 


\section{Conclusion}

The hostilities that broke out on the Thai-Cambodian border in 2008 escalated into armed clashes as both countries claimed sovereignty over a disputed area surrounding the Preah Vihear Temple. This tension damaged bilateral relations between the two countries and threatened peace and stability in the Southeast Asian region. Both countries have tried to settle this competing claim through existing bilateral mechanisms - for example, by referring to an MOU established in 2000 between the two countries. However, such a bilateral approach could not possibly survive the antagonistic nationalist forces in each country that pressed for use of military force to defend their territorial sovereignty. The Cambodian position has been clear with regards to the border conflict with Thailand. However, due to lack of confidence in the bilateral process, the Cambodian government placed little hope in existing bilateral mechanisms. Thus, it turned its attention to multilateral frameworks to try to settle the border dispute. Cambodia was able to convince the regional and international community to help mediate the situation.

As for Thailand, its position is rather complex. The crisis arose at a time of domestic political violence, from 2006 to mid-2010, a period in which Thailand was wracked by turmoil and street protests. Although Thailand insisted on bilateral mechanisms to resolve the border dispute, it failed to create an environment conducive for convincing Cambodia of the merits of this approach. The complications emerged mainly due to the nationalist PAD and the Thai army, who were seeking to play dominant roles in Thai politics. They exerted relentless pressure on the Thai government to adopt a tough stance toward Cambodia by fuelling the security dispute at the border under the pretext of protecting Thai sovereignty. For its own political gain, the Thai government dragged its feet on the bilateral process and refused all settlement options proposed by the international community. In response, the Cambodian government called upon the UNSC and ASEAN to mediate the border conflict.

The situation at the border has improved noticeably since the new Pheu Thai Party-led government of Yingluck came to power in August 2011. There was a resumption of talks - both the JBC in February 2012 and the GBC in April 2012-in an effort to restart bilateral negotiations. However, in order for these talks to prevent a new round of hostilities and effectively yield good results, positive change in the internal political dynamics of one or both countries must take place. Nationalist movements that often capitalize on domestic political interests, forcing their respective governments to lean in their direction, particularly in Thailand, must be tamed. The hope placed in ASEAN's dispute settlement mechanisms has proven to be disappointing. ASEAN itself has many limitations: the lack of instrumental enforcement, the absence of compliance on 
the part of its members, the leadership crisis, a missing common stance, and the interference of outside powers in the ASEAN process. The choice of approachesbilateral or through ASEAN - as the preferred mechanism for settling the border dispute will remain a difficult one, and so tensions could linger on for many more years. What is important is to defuse border tension by a process of building mutual trust and confidence between the two countries (Charnvit, Sothirak, and Pavin forthcoming). This process requires reducing military tensions at the border area by withdrawing troops, engaging in sincere dialogue, and allowing diplomatic efforts to work their magic.

\section{Notes}

The author would like to thank Professor Charnvit Kasetsiri, Ambassador Pou Sothirak, and two anonymous reviewers for their suggestions and comments on this article.

1. See, http://antithaksin.wordpress.com/2008/10/16/preah-vihear-for-koh-kong-andnatuaral-gasoil/, 2009 (accessed January 20, 2013).

2. His interview can be found at http://www.youtube.com/watch?v=_UCi-mgmIDs.

3. In Policy Statement of the Council of Ministers, delivered by Prime Minister Abhisit Vejjajiva, at the National Assembly, December 31, 2008. Personal copy. On page 8, although it does not indicate Cambodia as the primary threat, it states the need to protect national sovereignty as his government's second priority, after defending the monarchy. It says, "Strengthen and develop national defence capability in safeguarding the independence, sovereignty and territorial integrity of the state, as well as in protecting the national interest, by enhancing the preparedness of the armed forces, training troops in the conduct of operations, and aligning the budget of the armed forces with their respective missions...." 4. See the video clip at http://www.youtube.com/watch?v=BChWigFiuXQ\&feature=rela ted (accessed August 30, 2011).

5. See http://www.aseansec.org/25924.htm (accessed August 30, 2011).

6. The Joint Border Committee (JBC) has its main responsibility in discussing the survey and demarcation of the common border. Meanwhile, the General Border Committee (GBC) deals with more general border issues, such as landmine disposal, drug smuggling, human traffic, and land and maritime security issues.

7. See statement by the Chairman of ASEAN following the Informal Meeting of the Foreign Minister of ASEAN, Jakarta, February 22, 2011. http://www.asean.org/documents/ N110222.pdf (accessed April 25, 2012).

8. My discussion with a senior government official of Cambodia. The discussion took place in Phnom Penh, February 22, 2012.

9. The "ASEAN way" is said to contribute durability and longevity within the organization, by promoting regional identity and enhancing a spirit of mutual confidence and cooperation. ASEAN agreements are negotiated in a close, interpersonal process. The process of consultations and consensus is designed to engender a democratic approach to decision making. These leaders are wary of any effort to legitimize efforts to undermine their nation or contain regional co-operation. 


\section{References}

Bangkok Post. 2009. “Thailand Rejects Phnom Penh's Demand for Damages.” May 12.

Bangkok Post. 2011a. "Clips Show Panich in Cambodia." January 4.

Bangkok Post. 2011b. "Cluster Bomb Claim Denied." April 4.

Bangkok Post. 2011c. "Military's Worst Enemy is History." April 27.

Bangkok Post. 2013. "Veera, Ratree Nearer to Freedom." January 10.

BBC News. 2011. “Thai-Cambodia Clashes Damage Preah Vihear Temple.” February 6. http://www.bbc.co.uk/news/world-asia-pacific-12377626 (accessed August 30, 2011).

Bercovitch, Jacob. 2008. "Third Parties and Conflict Management in the Context of East Asia and the Pacific." In Conflict Management, Security and Intervention in East Asia: Third Party Mediation in Regional Conflict, eds. Jacob Bercovitch, Kwei-Bo Huang, and Chung-Chiang Teng. Oxon: Routledge.

Business Day. 2011. “Thai-Cambodian Trade Stalled by Border Clashes.” February 5. http:// www.bday.net/thai-cambodian-trade-stalled-by-border-clashes/ (accessed November 4, 2012).

Cambodia Daily News. 2011. “Cambodia PM Congratulates Thailand's Newly Elected PM.” August 5. http://cambodianewstoday.blogspot.jp/2011/08/cambodian-pmcongratulates-thailands.html (accessed April 15, 2013).

Charnvit, Kasetsiri, Pou Sothirak, and Chachavalpongpun Pavin. 2013. A Guide to the Thai Cambodian Conflict and Its Solutions. Forthcoming.

Cheang, Sopheng. 2008. "Thai-Cambodia in Military Standoff." Associated Press, July 21. http://newsgroups.derkeiler.com/Archive/Soc/soc.culture.cambodia/2008-07/ msg00369.html (accessed December 30, 2012).

Cichen, Shen, and Wang Yu. 2012. "South China Sea Code of Conduct Stranded in Distrust." Caijing. http://english.caijing.com.cn/2012-12-04/112333247.html (accessed January 1, 2013).

Croissant, Aurel, and Paul W. Chambers. 2011. "A Contested Site of Memory: The Preah Vihear Temple." In Cultures and Globalisation: Heritage, Memory and Identity, eds. Yudhishthir Raj Isar and Helmut K. Anheier. London: SAGE Publications.

Haacke, Jürgen. 2003. ASEAN Diplomatic and Security Culture: Origins, Development and Prospects. London: Routledge.

Hernandez, Carolina G. 1996. "Controlling Asia's Armed Forces." In Civil-Military Relations and Democracy, eds. Larry Jay Diamond and Marc F. Plattner. Maryland: The John Hopkins University Press.

Jagan, Larry. 2003. "Analysis: The Tension behind the Riots." BBC News, January 30. http:// news.bbc.co.uk/2/hi/asia-pacific/2709699.stm (accessed April 15, 2013).

Jory, Patrick. 2008. "Problems in Contemporary Thai Nationalist Historiography." Review Essay. Kyoto: Centre for Southeast Asian Studies. http://kyotoreview.cseas.kyoto-u. ac.jp/issue/issue2/article_251.html (accessed August 30, 2011).

Kurus, Bilson. 1993. "Understanding ASAEN: Benefits and Raison d'Etre." Asian Survey 33 (8): 819-31.

Macan-Markar, Marwaan. 2009. “Thai-Cambodia Tension Gives Rise to Schools with Bunkers." Inter Press Service, November 24. http://ispsnews.net/newsasp?idnews= 49385 (accessed June 23, 2010). 
Ministry of Foreign Affairs of Thailand. 2007. Handbook on Thailand's Political Situation. Bangkok: Department of Information, Ministry of Foreign Affairs of Thailand.

Mumthit, Ker. 2008. "Thailand Ready to Respond to Cambodian Threat." Mail and Guardian Online, October 14. http://mg.co.za/article/2008-10-14-thailand-ready-torespond-cambodian-threat (accessed August 30, 2011).

Nugroho, M. Santoso E. 1994. "ASEAN and Security in Southeast Asia." M.A. diss. Naval Postgraduate School.

Panitan, Watttanayagorn. 1998. "Thailand: The Elite's Shifting Conceptions of Security.” In Asian Security Practice: Material and Ideational Influences, ed. Muthiah Alagappa. California: Stanford University Press.

Penh, Phnom. 2011. “Cambodian PM Congratulates Thailand's New-elected Prime Minister.” Sinhwa News, August 5. http://news.xinhuanet.com/english2010/ world/2011-08/05/c_131032214.htm (accessed August 31, 2011).

Perry, Richard Lloyd. 2008. "Cambodian Threaten Wars over Temple Dispute." Times Online, October 14. http://www.timesonline.co.uk/tol/news/world/asia/ article4940025.ece (accessed August 17, 2011).

Prachathai. 2008. “Sondhi Limthongkul's Solution to the Preah Vihear Dispute." August 2. http://www.prachatai.com/english/news.php?id=732 (accessed March 29, 2009).

Ramcharan, Robin. 2000. "ASEAN and Non-Interference: A Principle Maintained." Contemporary Southeast Asia 22 (1): 60-88.

Rasak, Tan Sri Ahmad Fuzi bin Abdul. 2009. "Facing Unfair Criticisms.” In The Making of the ASEAN Charter, eds. Tommy Koh, Rosario G. Manalo, and Walter Woon. Singapore: World Scientific Publishing Company.

Reuters. 2008. “Thai PM’s Foes Throw Nationalist Temple Tantrum.” June 25.

Roberts, John. 2008. “Thai Military Plays Key Role in Forming New Government.” World Socialist Web Site, December 11. http://www.wsws.org/articles/2008/dec2008/ thai-d11.shtml (accessed 30 August 30, 2011).

Rodas, Albeiro. 2012. "ICJ Announced Preah Vihear Temple Hearings." Asian Correspondent, November 29. http://asiancorrespondent.com/92722/icj-announcedhearings-for-preah-vihear-temple/ (accessed January 21, 2013).

Severino, Rodolfo C. 2006. Southeast Asia in Search of An ASEAN Community: Insights from the Former ASEAN Secretary-General. Singapore: Institute of Southeast Asian Studies.

Straits Times. 2011. “Temple Ruins at Centre of Unrest.” April 28.

Sukma, Rizal. 2009. “A Post ASEAN-Foreign Policy for a Post G-8 World.” Jakarta Post, October 5.

Supalak, Ganjanakhundee. 2009a. "Thailand Recalls Ambassador to Protest Cambodia." The Nation, November 5.

Supalak, Ganjanakhundee. 2009b. "Hun Sen Settling Scores but is it Worth it?" The Nation, November 7.

Termsak, Chalermpalanupap. 2010. "Code of Conduct over the South China Sea." The Nation, September 4.

The Nation. 2009. "Preah Vihear Appeal Targets UN, Not Cambodia.” July 21.

Thiradej, Iamsamran, and Indaravichit Ram. 2008. Thodsalak khadi prasat phra viharn: wiwatha Guru sudyod haeng thosawad [Decoding the Phra Viharn Temple Case: Opinion of the Guru, The Best of the Decade]. Bangkok: Matichon Publishing House, 
62-3.

Thongchai, Winichakul. 2008. “Preah Vihear Can Be Time Bomb.” The Nation, June 30.

Thongchai, Winichakul. 2011. "Sia dindan pen prawatthisat lokphrai paitaithan proah Thai maikuei sia dindan" [Lost Territories is a Distorted History which Tricked the Lowly Peasants to Die for their Country because Thailand has Never Lost its Territories]. Matichon Online, February 8. http://www.matichon.co.th/news_detail. php?newsid=1297151137 (accessed August 30, 2011).

Waddhana, P. 2011. “The Strategy: Taking Cambodia Hostage Will Lead to a Military Coup and War." Agence Kampuchea Presse, January 31. http://www.akp.gov.kh/?p=1498 (accessed August 30, 2011).

Wassana, Nanuam, and Ruangdit Pradit. 2011. "Prawit Rejects GBC Meeting in Indonesia." Bangkok Post, March 23.

Wassana, Nanuam, Tansubhapon Thanida, and Tangprasert Prasit. 2009. "Thailand Shuts Tourist Spots after Fatal Clashes." Bangkok Post, April 4.

Wassana, Nanuam. 2011. "Prayuth: Indonesian Observers Not Wanted." Bangkok Post, March 23.

Weaver, Matthew. 2008. "Thailand Prime Minister to Step Down after Court Strips Him of Office.” The Guardian, December 2. http://www.guardian.co.uk/world/2008/dec/02/ thailand-protests-somchai-wongsawat (accessed August 27, 2011).

Xinhua News. 2011. “Thailand Non-committal to Joining Proposed Border Meeting with Cambodia.” March 10. http://khmernz.blogspot.com/2011/03/thailand-noncommittal-to-joining.html (accessed April 26, 2012).

Pavin Chachavalpongpun is Associate Professor at the Center for Southeast Asian Studies, Kyoto University. Earning his Ph.D. from the School of Oriental and African Studies, University of London in 2002, Pavin was a lead researcher in the Political and Strategic Affairs at the ASEAN Studies Centre, Singapore's Institute of Southeast Asian Studies. Pavin is the author of two books: A Plastic Nation: The Curse of Thainess in Thai-Burmese Relations and Reinventing Thailand: Thaksin and His Foreign Policy. He is also contributor to a number of articles related to the issues of ASEAN and the Thai-Cambodian relations, including "The Temple of Doom: Hysteria about the Preah Vihear Temple in the Thai Nationalist Discourse," in Legitimacy Crisis in Thailand (2010). 